Review

\title{
Positive and Negative Impacts of Non-Native Bee Species around the World
}

\author{
Laura Russo \\ Mueller Lab, Biology Department, Pennsylvania State University, University Park, PA 16802, USA; \\ lar322@psu.edu \\ Academic Editor: Mary L. Cornelius \\ Received: 30 October 2016; Accepted: 18 November 2016; Published: 28 November 2016
}

\begin{abstract}
Though they are relatively understudied, non-native bees are ubiquitous and have enormous potential economic and environmental impacts. These impacts may be positive or negative, and are often unquantified. In this manuscript, I review literature on the known distribution and environmental and economic impacts of 80 species of introduced bees. The potential negative impacts of non-native bees include competition with native bees for nesting sites or floral resources, pollination of invasive weeds, co-invasion with pathogens and parasites, genetic introgression, damage to buildings, affecting the pollination of native plant species, and changing the structure of native pollination networks. The potential positive impacts of non-native bees include agricultural pollination, availability for scientific research, rescue of native species, and resilience to human-mediated disturbance and climate change. Most non-native bee species are accidentally introduced and nest in stems, twigs, and cavities in wood. In terms of number of species, the best represented families are Megachilidae and Apidae, and the best represented genus is Megachile. The best studied genera are Apis and Bombus, and most of the species in these genera were deliberately introduced for agricultural pollination. Thus, we know little about the majority of non-native bees, accidentally introduced or spreading beyond their native ranges.
\end{abstract}

Keywords: bees; competition; genetic introgression; impacts; invasive species; pollination; species introductions

\section{Introduction}

The accidental introduction of some invasive insects can decimate ecosystems [1] or cause billions of dollars of environmental [2], crop [3], or building damage [4]. The majority of these insects are not noted for their potential positive impacts. On the other hand, some insects have been deliberately introduced for the services they provide to humans, without full consideration for their potential negative impacts. These insects may spread beyond the areas where they have been deliberately introduced and even become invasive pests in some cases [5]. Bees are one such group of insects, often introduced for their pollination services, but also with the potential to have negative economic and environmental impacts.

Bee species have been both introduced accidentally and deliberately around the world. Perhaps the most well-known of these introduced bee species is the European Honeybee (Apis mellifera), the most managed bee in the world, but over 70 other species have become established outside of their native ranges. There is increasing concern about the potential negative effects of these introduced bees, and there have even been efforts to eradicate them in some areas [6]. However, most attention is focused on the highly abundant and widely introduced species, including A. mellifera and Bombus terrestris as well as the managed solitary bee, Megachile rotundata.

Most non-native bee species are accidentally introduced and the potential negative and positive impacts to their introductions have not been explored. Learning about the potential impacts of 
introduced bees is particularly important as new species are still being proposed for domestication, and ranges will continue to change naturally and through human transportation. The purpose of this review is to collate information on all recorded non-native bee species around the world, and to discuss some of the potential outcomes of their introductions. I reviewed over 450 papers (266 of those papers are cited in this manuscript: 145 in the main text and tables and the remainder in the supplementary tables) addressing the distributions and impacts of introduced bees around the world, and present recorded positive and negative impacts here.

\section{Non-Native Bee Species}

For the purposes of this paper, a non-native species is defined as having one or more populations outside of its historical range. Non-native species can have both negative and positive impacts [7]. Non-native species with recognized negative impacts which are difficult to control are often referred to as "invasive" and some bee species with non-native populations are referred to in this way. However, because of the widely recognized beneficial impacts of bees, and the fact that they are often deliberately introduced, not all non-native bee species are considered invasive. Thus, I will simply refer to them as non-native species here.

The literature reviewed by the author included 80 recorded non-native bee species from 30 genera around the world (Table 1). These non-native bees are unevenly distributed among the 7 bee families, suggesting attributes of some bee families might make them more likely to have adventive or invasive species. Melittidae and Stenotritidae are not represented by any recorded non-native species. The mining bee family, Andrenidae, is only represented by one non-native species (Andrena wilkella), while both Colletidae and Halictidae have 8 non-native representatives. Indeed, the non-native bees are dominated by representatives of the families Megachilidae (33 non-native species) and Apidae (30 non-native species), though some of the other families have fewer species overall and are thus less likely to have invasive representatives. With 13 non-native species, Megachile is the best represented genus.

The majority $(73 \%)$ of the bee species with non-native populations were likely accidentally introduced, while a minority (18\%) were deliberately introduced, and a small number (5\%) naturally expanded their ranges. The introduction history of the remainder is still uncertain. The majority $(69 \%)$ of all non-native bee species nest in stems, twigs, existing cavities, or holes they bore into wood, while a smaller number $(26 \%)$ nest in the ground, and very few (5\%) have exposed nests. The proportion of bees that nest in stems, twigs, or other cavities increases to $77 \%$ when only accidentally introduced species are considered. Ten of the non-native species are suspected to be oligolectic and have likely been transported with their plant hosts. There are only two cleptoparasitic species represented among the non-native bees, though some non-native Sphecodes have been found in Hawaii (pers. comm. S. Droege). 
Table 1. A list of non-native bee species around the world, sorted by family and including their probable method of introduction (deliberately introduced: I; accidentally introduced: A; naturally expanding or shifting range: N), year of introduction, origin, and known areas of introduction. Question marks (?) represent uncertainty in the timing or distribution of introduced and native range. This often occurs when the bee fauna of a given area has only recently been studied and in some cases the non-native species has potentially been present for a long time.

\begin{tabular}{|c|c|c|c|c|c|c|}
\hline Colletidae (8) & Non-native Species & & Year & From & Found in & Reference \\
\hline \multirow[b]{8}{*}{ Andrenidae (1) } & Chilicola rostrata & A & 2008 & Argentina & Chile & [8] \\
\hline & Hylaeus (Prosopis) variegates & A & 1990 & North Africa & New York City & pers. comm. S. Droege \\
\hline & $\begin{array}{l}\text { Hylaeus albonitens } \\
\text {. }\end{array}$ & A & 1995 & Australia & Hawaii & [9] \\
\hline & Hylaeus hyalinatus & A & 1990 & Europe & $\begin{array}{c}\text { New York City, S Ontario, New Jersey, } \\
\text { Pennsylvania }\end{array}$ & {$[10,11]$} \\
\hline & $\begin{array}{l}\text { Hylaeus punctatus } \\
\text { Hens }\end{array}$ & A & 1980 & $\begin{array}{l}\text { Europe } \\
\text { Europe }\end{array}$ & US, Chile, Canada, Argentina, Brazil & $\begin{array}{l}{[y, 11,1]} \\
{[11]}\end{array}$ \\
\hline & Hylaeus strenuus & A & 2007 & Asia & Hawaii & {$[13,14]$} \\
\hline & Hyleoides concinna & A & 1980 & Australia & New Zealand & [15] \\
\hline & & 1 & $1000 \mathrm{c}$ & Furone and Aci & NE ULS and SC C & \\
\hline \multirow{9}{*}{ Halictidae (8) } & Andrena wilkella & A & $1900 \mathrm{~s}$ & Europe and $\mathrm{N}$ Asia & NE US and S Canada & {$[11,12,16]$} \\
\hline & Halictus tectus & A & 2000 & Europe to Mongolia & $\begin{array}{l}\text { Philadelphia, Baltimore, Washington, } \\
\text { DC }\end{array}$ & [12] \\
\hline & Lasioglossum eleutherense & A & 1990 & Bahamas and Cuba & Florida & pers. comm. S. Droege \\
\hline & Lasioglossum imbrex & A & 2013 & US & Hawaii & {$[17,18]$} \\
\hline & Lasioglossum impavidum & A & 2003 & W US & Hawaii & [9] \\
\hline & Lasioglossum leucozonium & A & $1900 \mathrm{~s}$ & Europe and North Asia & US and S Canada & {$[11,16]$} \\
\hline & Lasioglossum microlepoides & A & 2013 & continental US & Hawaii & {$[17,18]$} \\
\hline & Lasioglossum zonulum & A & $?$ & Europe and S China & North America & [11] \\
\hline & Nomia melanderi & I & 1970 & North America & New Zealand & [19] \\
\hline \multirow{14}{*}{ Megachilidae (33) } & Afranthidium (Immanthidium) & & & & & \\
\hline & $\begin{array}{l}\text { Afranthidium (Immanthidium) } \\
\text { repetitum }\end{array}$ & A & 2000 & Africa & Australia & [20] \\
\hline & $\begin{array}{c}\text { repettitum } \\
\text { Anthidium manicatum }\end{array}$ & A & 1960 & Europe, N Africa, Near East & $\begin{array}{c}\text { Chile, Brazil, Argentina, Uruguay, } \\
\text { the US, Canada, New Zealand, Siberia, } \\
\text { Peru, Suriname, Paraguay }\end{array}$ & {$[11,12,16]$} \\
\hline & Anthidium oblongatum & A & 1990 & Europe and Near East & NE US and S Canada & {$[11,12]$} \\
\hline & Anthidium vigintiduopunctatum & A & 2006 & South America, Ecuador, Peru & Galapagos, Fiji? & {$[21,22]$} \\
\hline & Chelostoma campanularum & A & 1960 & Europe and Near East & New York, Connecticut, and S Ontario & {$[11,23]$} \\
\hline & Chelostoma rapunculi & A & 1960 & Europe and Near East & New York and S Ontario & {$[11,23]$} \\
\hline & Coelioxys coturnix & A & 2000 & $\begin{array}{l}\text { Europe, North Africa, } \\
\text { Mediterranean. India? }\end{array}$ & E US & pers. comm. S. Droege \\
\hline & Heriades truncorum & A & 2010 & Europe and Near East & Maryland & pers. comm. S. Droege \\
\hline & Hoplitis adunca & & 2016 & Europe, Asia, Africa & Britain & [24] \\
\hline & Hoplitis anthocopoides & A & 1960 & Europe & US, S Ontario & {$[11,25]$} \\
\hline & Lithurgus bractipes & A & $?$ & ? & Fiji & [26] \\
\hline & Lithurgus chrysurus & A & 1970 & Europe, Near East, N Africa & Pennsylvania and New Jersey & [12] \\
\hline & Lithurgus huberi & A & 1907 & Asia & South America, Argentina & [27-29] \\
\hline
\end{tabular}


Table 1. Cont.

\begin{tabular}{|c|c|c|c|c|c|c|}
\hline Colletidae (8) & Non-native Species & & Year & From & Found in & Reference \\
\hline \multirow{27}{*}{ Apidae (30) } & Lithurgus scabrosus & $\mathrm{A}$ & 1907 & \multirow{3}{*}{$\begin{array}{c}\text { Europe } \\
\text { Europe, N Africa, Near/Middle } \\
\text { East }\end{array}$} & Hawaii, Vanuatu & [9] \\
\hline & Megachile apicalis & A & 1930 & & US, Canada & {$[11,12]$} \\
\hline & Megachile australis & A & & & Vanuatu, Samoa & [26] \\
\hline & Megachile chlorura & $\mathrm{A}$ & 1988 & Philippines & Hawaii & [9] \\
\hline & Megachile concinna & A & 1940 & Africa & West Indies, Mexico, US, Argentina & [12] \\
\hline & Megachile ericetorum & A & 2000 & Europe, Near East, China & S Ontario and New York & [11] \\
\hline & Megachile fullawayi & A & 1921 & Guam & Hawaii & [30] \\
\hline & Megachile gentilis & A & $?$ & W US & Hawaii & {$[9,31]$} \\
\hline & Megachile lanata & A & $1700-1800$ & India and China & $\begin{array}{l}\text { West Indies and N South America, } \\
\text { Florida, Antilles, Hawaii }\end{array}$ & [32] \\
\hline & Megachile rufipennis & A & $1511-1867$ & Old World & Canaad, Dentilles & [32] \\
\hline & Megachile sculpturalis & A & 1990 & Far east China, Korea, Japan & US, S Canada, Europe & {$[11,12,34,35]$} \\
\hline & Megachile timberlakei & A & 2010 & Hawaii? & Galapagos & {$[9,22,36]$} \\
\hline & Megachile umbripenne & A & 2013 & S Asia & Fiji, Samoa, Hawaii? & {$[9,26]$} \\
\hline & Osmia caerulescens & A & $1800 \mathrm{~s}$ & $\begin{array}{l}\text { Europe, N Africa, Near East, } \\
\text { India }\end{array}$ & US, S Canada, New Zealand & {$[11,12]$} \\
\hline & Osmia cornifrons & I & 1960 & East China, Japan & US, Denmark, Korea & [12] \\
\hline & Osmia cornuta & I & 1980 & Europe, N Africa, Near East & establishment not documented & [37] \\
\hline & Osmia ribifloris & I & 1991 & W US & Maine/E US, establishment uncertain & [38] \\
\hline & Osmia taurus & $\mathrm{A}$ & 2000 & East China, Japan & E US, Michigan & [16] Gibbs et al in prep \\
\hline & Pseudoanthidium nana & $\mathrm{A}$ & 2000 & Europe and Near East & NE US & pers. comm. S. Droege \\
\hline & Anthophora villosula & I & 1980 & Japan & $\begin{array}{l}\text { FII } \\
\text { E US }\end{array}$ & [12] \\
\hline & Apis cerana & A & 2007 & Asia & $\begin{array}{l}\text { Australia, Russia, Iran (Crane 1995), } \\
\text { Papua New Guinea (Bradbear and } \\
\text { MacKay 1995), Samoa, Fiji, Vanuatu }\end{array}$ & [40] \\
\hline & Apis dorsata & A & $?$ & Asia & $\begin{array}{l}\text { Japan } \\
\text { Jachat, valluatu }\end{array}$ & {$[41]$} \\
\hline & Apis florea & I & 1985 & Oman, Asia, Indonesia & Iraq, Sudan (Glaiim 2005) & {$[42-45]$} \\
\hline & Apis mellifera & I & 1620 & N Europe, Meditteranean & globally introduced & {$[11,12]$} \\
\hline & Bombus hortorum & I & 1885 & UK & $\begin{array}{l}\text { New Zealand } \\
\text { New Z }\end{array}$ & [19] \\
\hline & Bombus hypnorum & $\mathrm{N}$ & 2001 & Europe & UK & {$[46,47]$} \\
\hline & Bombus impatiens & I & 2003 & North America & $\begin{array}{l}\text { Chile, Mexico, Central America, } \\
\text { Canada }\end{array}$ & {$[33,48]$} \\
\hline
\end{tabular}


Table 1. Cont.

\begin{tabular}{|c|c|c|c|c|c|c|}
\hline \multirow[t]{19}{*}{ Colletidae (8) } & \multicolumn{2}{|l|}{ Non-native Species } & \multirow{2}{*}{$\begin{array}{l}\text { Year } \\
1981\end{array}$} & \multirow{2}{*}{$\begin{array}{c}\text { From } \\
\text { Europe, China }\end{array}$} & \multirow{2}{*}{$\begin{array}{c}\text { Found in } \\
\text { Iceland }\end{array}$} & \multirow{2}{*}{$\begin{array}{c}\text { Reference } \\
{[19]}\end{array}$} \\
\hline & & & & & & \\
\hline & Bombus ruderatus & I & 1885 & UK & New Zealand, Chile, Argentina, & {$[19,33,49]$} \\
\hline & Bombus subterraneous & I & 1885 & UK & New Zealand & [19] \\
\hline & Bombus terrestris & I & 1885 & UK & $\begin{array}{l}\text { Chile, China, Israel, Japan, Mexico, } \\
\text { South Africa, South Korea, New } \\
\text { Zealand, Tasmania, and Taiwan }\end{array}$ & {$[19,33,49-51]$} \\
\hline & Braunsapis puangensis & A & 2003 & Asia, india & Fiji & [52-55] \\
\hline & Centris nitida & A & 2000 & $\begin{array}{l}\text { SW US, Mexico, central, } \mathrm{S} \\
\text { America }\end{array}$ & Florida & [56] \\
\hline & Ceratina arizonensis & A & 1950 & W US & Hawaii & [9] \\
\hline & Ceratina dallatorreana & A & 1940 & Meditteranean & California & [57] \\
\hline & Ceratina dentipes & A & 1909 & $\begin{array}{l}\text { Turkey, Cyprus, S Asia, } \\
\text { Australia }\end{array}$ & $\begin{array}{l}\text { Vanuatu, Fiji, Samoa, Cook Islands, } \\
\text { Hawaii.Japan, Mauritius }\end{array}$ & [9] \\
\hline & Ceratina smaragdula & I & 1960 & Pakistan, India, SE Asia & Hawaii, Australia & [9] \\
\hline & Euglossa dilemma & A & 2000 & Mexico and Central America & Florida & [58] \\
\hline & Peponapis pruinosa & $\mathrm{N}$ & $?$ & Mexico & North America & [59] \\
\hline & Plebia frontalis & I? & 2010 & Mexico, Central, South America & California & pers. comm. S. Droege \\
\hline & Triepeolus remigatus & $\mathrm{N}$ & $?$ & Mexico & North America & pers. comm. S. Droege \\
\hline & Xenoglossa strenua & $\mathrm{N}$ & ? & Mexico & North America & pers. comm. S. Droege \\
\hline & Xylocopa appendiculata & A & 2010 & Japan and China & California & [60] \\
\hline & Xylocopa augusti & A & 2013 & Argentina & Chile & [61] \\
\hline & Xylocopa sonorina & I & ? & W US & $\begin{array}{l}\text { Samoa, Hawaii, Guam, Northern } \\
\text { Marianas Islands, Japan }\end{array}$ & {$[9,41,62]$} \\
\hline
\end{tabular}


Islands have the largest number of introduced bees, and indeed, 27 of the 80 non-native bee species are only non-native on islands (not counting Australia as an island). These non-native bee species sometimes become the most diverse and abundant component of the otherwise depauperate bee fauna of island ecosystems. For example, the Galapagos Islands have only one native bee species, but two non-native bee species have been introduced [22]. In the southwest Pacific islands of Fiji, Samoa, and Vanuatu, there is some evidence to indicate that most, if not all, apid and megachilid bees have been introduced by humans [26,64]. A similar situation likely exists in French Polynesia [39]. On the Hawaiian Islands, which likely have only 69 native bee species, there are 14 non-native bee species recorded $[9,17]$.

There are likely many more unrecorded introduced bee species. This list is dominated by species introduced to North America; 34 of the 80 species are only reported as non-native in North America, including Hawaii (25 excluding Hawaii). A total of 55 bee species (69\%) have been recorded as introduced to North America and it is unclear whether North America is truly more vulnerable to invasion or whether there is a sampling bias. As a contrast, there are relatively few non-native bees recorded in the well-studied European bee fauna.

\section{Impacts}

Outside of the genera Apis and Bombus, empirical evidence for impacts is sparse; for 25 species researchers have suggested hypothetical impacts, but have not measured impacts empirically. For an additional 29 species, there are neither hypothetical nor empirical impacts in the literature. For 13 species, there are potential negative impacts, but no potential positive impacts recorded in the literature, and, conversely, there are 11 species for which only potential positives are recorded. Thus, for more than two thirds of the non-native bee species distributed around the world, we have no empirical evidence of any impact of their introduction. This is not equivalent to evidence for the absence of an impact, though such evidence would be less likely to be published [65]. Moreover, it is more difficult to obtain evidence for some impacts than others. For example, it is easier to demonstrate that a non-native bee can pollinate an invasive weed than to show it competes with native bees, as the former can be directly measurable (Figure 1).

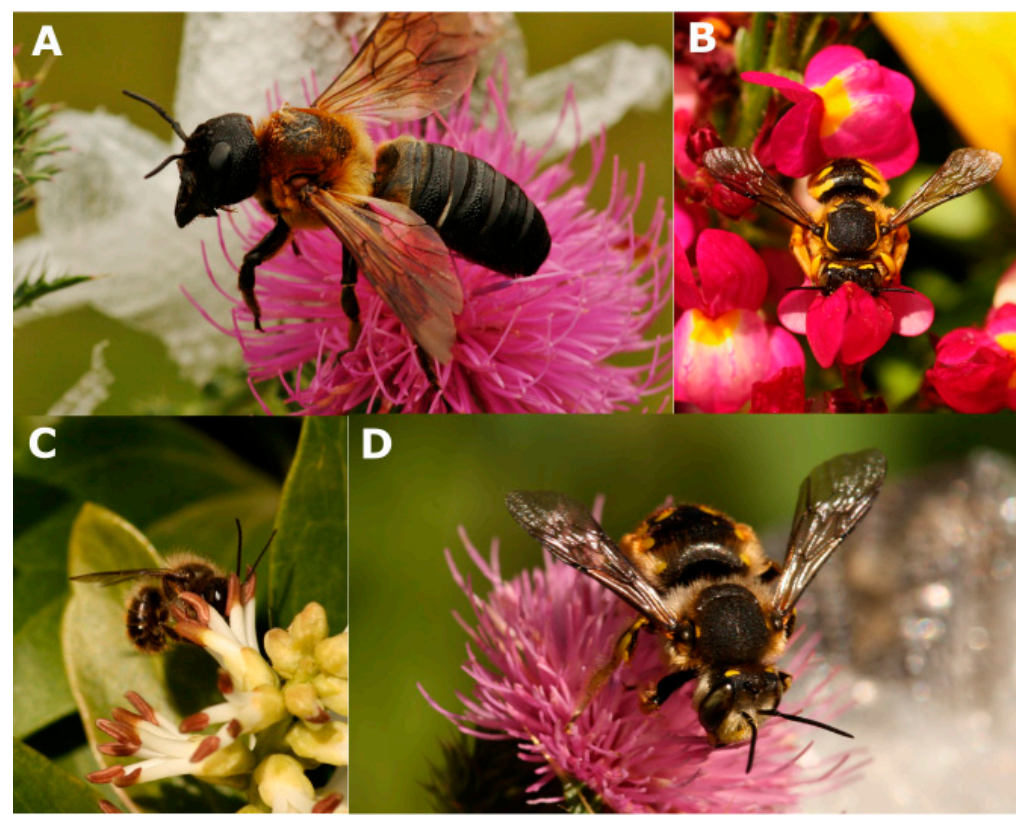

Figure 1. Non-native bees on non-native plants, including (A) Megachile sculpturalis on Carduus acanthoides; (B) Anthidium manicatum on Linaria reticulata; (C) Osmia cornifrons on Pachysandra terminalis; and (D) Anthidium manicatum on Carduus acanthoides. Photographs by the author. 


\section{Negative Impacts}

Goulson [19] conducted a review of the potential negative impacts of 17 non-native bees, which he listed as competition for floral resources or nesting sites, transmission of pathogens or parasites, affecting the seed set of native plants, and pollinating invasive plant species. However, many bee species were introduced after 2000 (Figure S1) and several additional negative impacts have been mentioned in the literature, including alteration of pollination networks, damage to buildings, and genetic introgression through hybridization of managed populations/species with wild populations/species.

\subsection{Apis/Bombus}

Because entire reviews have been written just on the impacts of the introduced species from the Apis and Bombus genera (e.g., [66-69]), I have collated selected references for these genera in separate tables in the supplementary materials. Despite the abundance of research on these two genera, the literature is still mixed on their potential impacts and the results of many studies are either inconclusive or contradictory [66]. For example, there is both abundant evidence that honeybees can reduce the pollination of native plants, and also that they can improve the pollination of native plants (Tables S1 and S2). Some also argue that introduced Apis only have negative impacts on other members of their own genus [70]. The negative impact of genetic introgression has only been recorded for Apis/Bombus, and there seems to be some strong empirical support for this potential outcome in Bombus terrestris. Though there is some empirical support for all negative impacts (except damage to buildings) across these two genera, there are also some studies that record the absence of competition, pollination of invasive weeds, and decreasing the fitness of native plants. The only category where there is plenty of empirical support and no contradicting studies is the spread of parasites and pathogens introduced along with Apis/Bombus species (Table S1).

\subsection{Other Genera}

The strongest evidence for negative impacts in non-Apis/Bombus species is in competition for floral resources, transmission of parasites and pathogens, and pollination of invasive weeds. However, there is little empirical evidence that these non-native bees compete for floral resources and there is empirical evidence demonstrating a lack competition in several cases (Table 2). There only seems to be evidence for nesting competition with native species in the genus Megachile and the potential economic negative of damage to buildings has only been hypothetically recorded for Lithurgus chrysurus [71,72], though some other wood boring species may also have this potential. There is no empirical support for the potential of these non-Apis/Bombus species to degrade pollination networks or to negatively affect the pollination of native plant species, but there is some concern in the literature that several species will have this effect, particularly on islands [26].

If hypothetical impacts can be considered a measure of the relative amount of concern about the introduction of a given species, the European Wool Carder bee (Anthidium manicatum), is the most concerning of the non-Apis/Bombus introduced bees. Indeed, the range of this species has increased rapidly in recent years, and it seems to be approaching a global distribution [73]. There is evidence that the non-native Osmia cornifrons and O. cornuta and their native congener O. lignaria can share some parasites [74,75], though the potential for the introduced bee to spread the parasite to native bee species has not been explored. In contrast, the most empirical evidence for negative impacts seems to be for the globally introduced managed Alfalfa Leaf Cutter Bee (Megachile rotundata) and the accidentally introduced Taiwanese bamboo carpenter bee (Xylocopa tranquebarorum). 
Table 2. Potential negative impacts of non-Apis or Bombus species, including competition for nesting sites and floral resources, co-introduction with pathogens or parasites, pollination of invasive weeds, alteration of resident pollination networks, damage to buildings, and changing pollination of native plant species. Bold and underlined text refers to citations with an empirical component while unbolded text refers to papers that refer to impacts only from a hypothetical standpoint. Light grey shading indicates species for which neither positive nor negative impacts have been recorded, while dark grey indicates species for which only positive impacts have been recorded. "But see" refers to manuscripts that show evidence or describe the opposite of the effect.

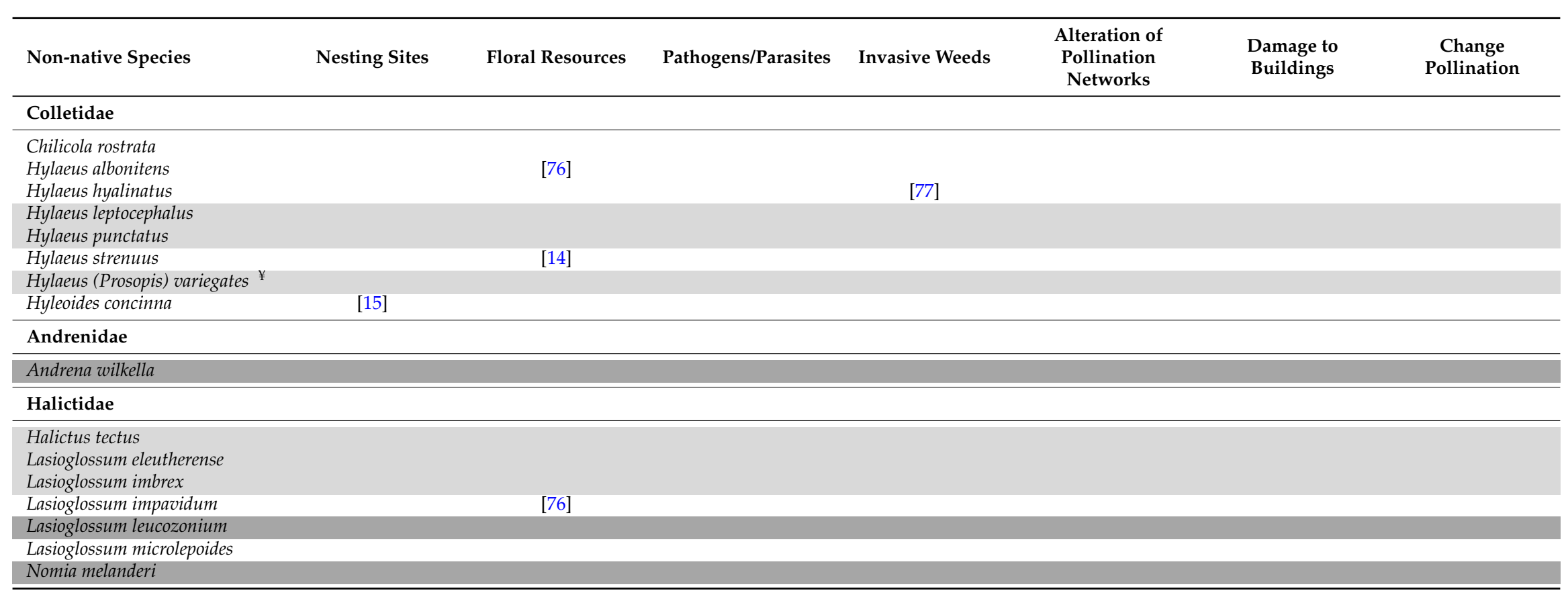


Table 2. Cont.

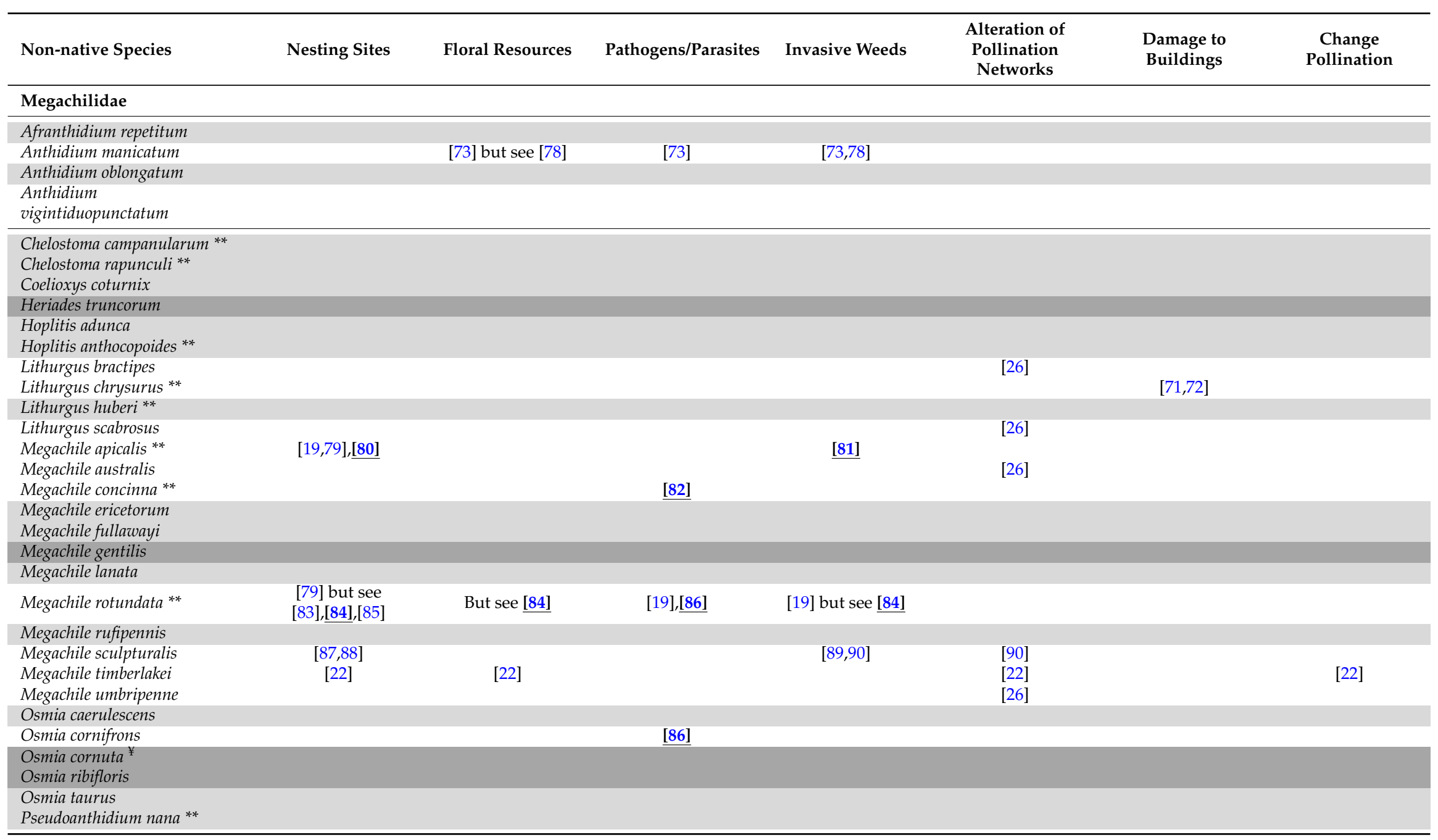


Table 2. Cont

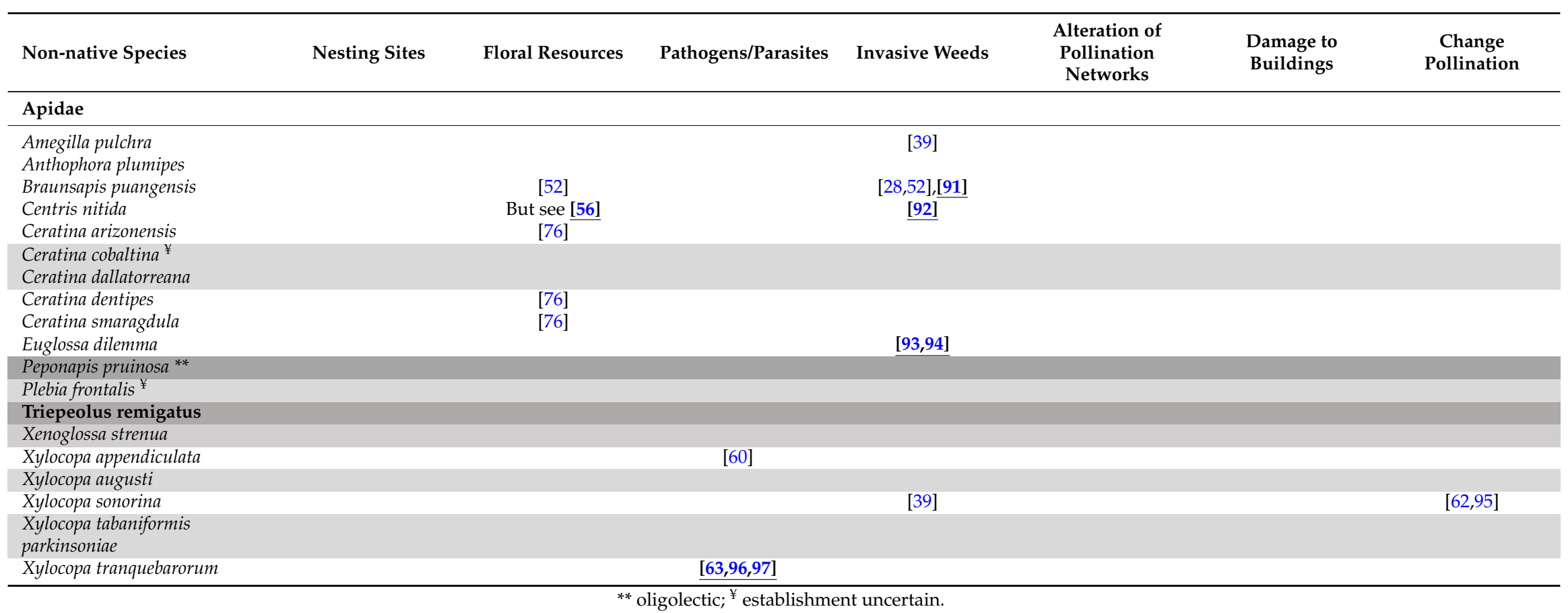




\section{Positive Impacts}

To the best of my knowledge the positive impacts of introduced bees have not been reviewed although the pollination services provided by diverse communities of bees are well known [98-101] and the interactions between native and non-native bees might even be beneficial in some cases [102]. Non-native bees can have positive impacts by pollinating agricultural crops, acting as biological control agents, rescuing native plant species whose native pollinators have been lost, increasing resilience to human disturbance and climate change, encouraging scientific investigations through lab rearing, serving as bio-indicators, and promoting the study of natural history.

\subsection{Apis/Bombus}

As with negative impacts, the positive impacts of the Apis and Bombus genera are reviewed in the supplemental materials (Table S2). They can have the same positive impacts as the other bee genera and, as with the negative impacts, are better studied in general. The majority of these bees were deliberately introduced for their pollination services to agriculture, which are widely recognized. However, their ease of management has also led to their utility as study species for scientific research. They have also been demonstrated to rescue native plant species when their native pollinators are in decline, though their role in the decline of these native pollinators is unclear (Table S1). It is also possible that their impacts on native pollinators are confounded with human disturbance, as several of these species are more resilient to human impacts.

\subsection{Other Genera}

In the non-Apis/Bombus genera, the strongest evidence for positive impacts comes unsurprisingly from the potential to be agricultural pollinators. There is likely a publication bias for this effect, as it confers an economic benefit to humans [103]. Several non-native bee species were deliberately introduced for their pollination services (Table 1), but this is also listed as a hypothetical benefit for many accidentally introduced bee species (Table 3).

Because deliberately introduced species are generally easy to manage and rear in a laboratory setting, many of these provide an additional benefit to science and are often used for pesticide, genetic, and behavioral studies. In the case of Osmia cornuta, they have even shown to be potentially useful for the application of biocontrol to manage invasive pest species in crops [13] or bioindicators for environmental quality [104]. Many other bee species have the potential to provide this benefit, particularly those that readily nest in hollow tubes as a high proportion of introduced bees do.

Finally, many of these non-native species have been accidentally spread by humans because they flourish in human-modified landscapes. These bee species have the potential to supplement pollination services where native species have been lost and demonstrate resilience to human disturbance and climate change. Indeed, several of the listed species have only been recorded in urban areas (e.g., Anthidium oblongatum [105], Pseudanthidium nana (pers. comm. S. Droege)). Bees capable of handling human disturbance and habitat degradation might not only provision crop species with pollination services, but also have the potential to rescue native plant species whose more sensitive native pollinators have been lost [106], though this has not yet been listed as a potential benefit of non-Apis/Bombus genera. 
Table 3. Potential positive impacts of non-Apis or Bombus species, including agricultural pollination, biocontrol of pest species, ability to encourage scientific research in lab-reared studies, as bioindicators, or for studies of natural history, and resilience to human disturbance and climate change. Bold and underlined text refers to citations with an empirical component while unbolded text refers to papers that refer to impacts only from a hypothetical standpoint. Light grey shading indicates species for which neither positive nor negative impacts have been recorded, while dark grey indicates species for which only negative impacts have been recorded. "But see" refers to manuscripts that show evidence or describe the opposite of the effect.

\begin{tabular}{|c|c|c|c|c|c|c|}
\hline Non-native Species & Agricultural Pollination & Biocontrol & Lab Reared & Bioindicators & Natural History & Resilience \\
\hline $\begin{array}{c}\text { Colletidae } \\
\text { Chilicola rostrata } \\
\text { Hylaeus albonitens } \\
\text { Hylaeus hyalinatus }\end{array}$ & & & & & & [77] \\
\hline \multicolumn{7}{|l|}{ Hylaeus punctatus } \\
\hline \multicolumn{7}{|l|}{ Hylaeus strenuus } \\
\hline \multicolumn{7}{|l|}{$\begin{array}{c}\text { Hylaeus (Prosopis) variegates } \\
\text { Hyleoides concinna }\end{array}$} \\
\hline \multicolumn{7}{|l|}{ Andrenidae } \\
\hline Andrena wilkella & [31] & & & & & [107] \\
\hline \multicolumn{7}{|l|}{ Halictidae } \\
\hline \multirow{2}{*}{\multicolumn{7}{|c|}{$\begin{array}{c}\text { Halictus tectus } \\
\text { Lasioglossum eleutherense } \\
\text { Lasioglossum imbrex }\end{array}$}} \\
\hline \multicolumn{6}{|l|}{ Lasioglossum impavidum } & \\
\hline $\begin{array}{l}\text { Lasioglossum leucozonium } \\
\text { Lasioglossum microlepoides }\end{array}$ & {$[108]^{*}$} & & & & & \\
\hline Nomia melanderi & {$[103],[109,110]$} & & & & & \\
\hline
\end{tabular}


Table 3. Cont.

\begin{tabular}{|c|c|c|c|c|c|c|}
\hline Non-native Species & Agricultural Pollination & Biocontrol & Lab Reared & Bioindicators & Natural History & Resilience \\
\hline \multicolumn{7}{|l|}{ Megachilidae } \\
\hline \multicolumn{7}{|l|}{ Afranthidium repetitum } \\
\hline Anthidium manicatum & & & [111] & & & \\
\hline \multicolumn{7}{|l|}{ Anthidium oblongatum } \\
\hline Anthidium vigintiduopunctatum & & & & & [26] & \\
\hline \multicolumn{7}{|l|}{ Chelostoma campanularum ** } \\
\hline \multicolumn{7}{|l|}{ Chelostoma rapunculi ** } \\
\hline \multicolumn{7}{|l|}{ Coelioxys coturnix } \\
\hline Heriades truncorum & & & [112] & & & \\
\hline \multicolumn{7}{|l|}{ Hoplitis adunca } \\
\hline \multicolumn{7}{|l|}{ Hoplitis anthocopoides ** } \\
\hline Lithurgus bractipes & [26] & & & & & \\
\hline \multicolumn{7}{|l|}{ Lithurgus chrysurus ** } \\
\hline \multicolumn{7}{|l|}{ Lithurgus huberi ** } \\
\hline & [26] & & & & & \\
\hline \multicolumn{7}{|l|}{ Megachile apicalis ** } \\
\hline Megachile australis & [26] & & & & & \\
\hline Megachile concinna ** & [113] & & & & & \\
\hline \multicolumn{7}{|l|}{ Megachile ericetorum } \\
\hline Megachile gentilis & [31] & & & & & \\
\hline \multicolumn{7}{|l|}{ Megachile lanata } \\
\hline Megachile rotundata ** & $\begin{array}{c}{[26,31],[38],[73,109,} \\
114],[\mathbf{1 1 5}],[116]\end{array}$ & & [116-119] & & [120] & \\
\hline \multicolumn{7}{|l|}{ Megachile rufipennis } \\
\hline \multicolumn{7}{|l|}{ Megachile sculpturalis } \\
\hline \multicolumn{7}{|l|}{ Megachile timberlakei } \\
\hline \multirow{2}{*}{\multicolumn{7}{|c|}{ Osmia caerulescens }} \\
\hline & & & & & & \\
\hline Osmia cornifrons & {$[109,114,121],[122-124]$} & & [125-127] & & & \\
\hline Osmia cornuta $¥$ & {$[109],[128],[129]$} & [130] & [131] & [104] & & \\
\hline Osmia ribifloris & {$[19],[38]$} & & & & & \\
\hline $\begin{array}{c}\text { Osmia taurus } \\
\text { Pseudoanthidium nana ** }\end{array}$ & & & & & & \\
\hline
\end{tabular}


Table 3. Cont.

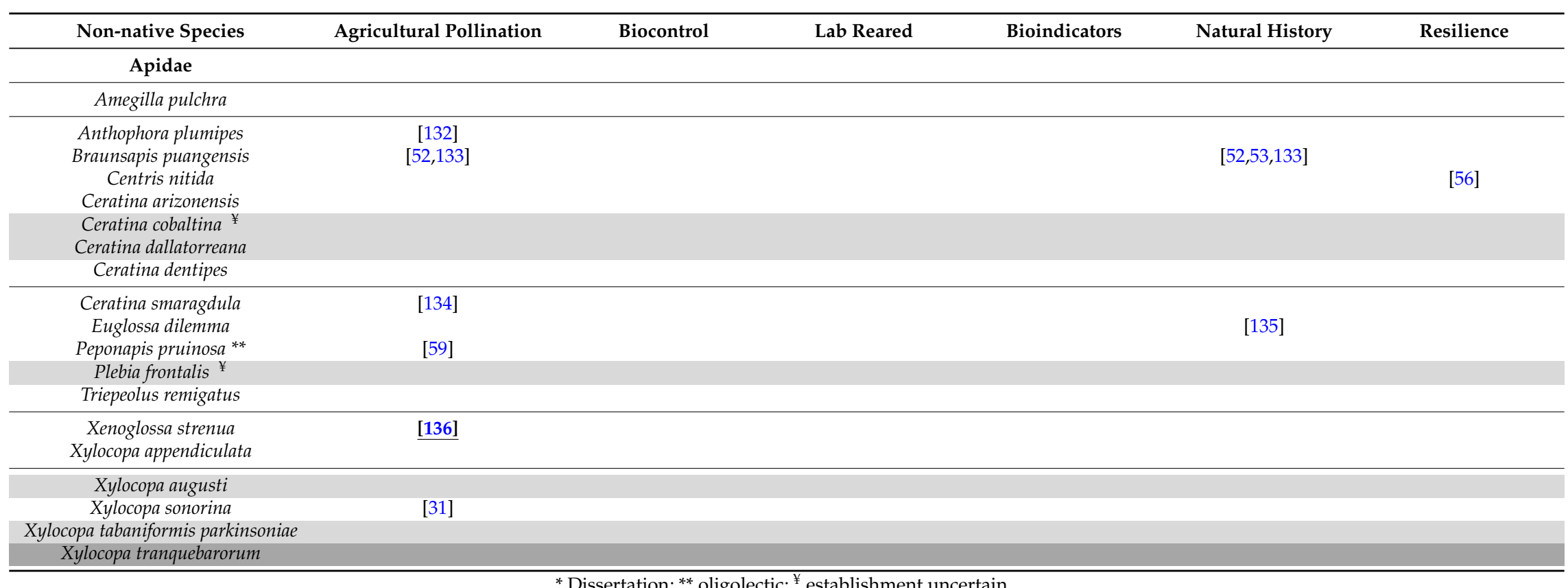

* Dissertation; ${ }^{* *}$ oligolectic; ${ }^{¥}$ establishment uncertain. 


\section{Discussion}

Though much research has been done on the impacts of bees in the Apis and Bombus genera, much less is known about the impacts of non-native bees in other genera. This is partly due to the fact that many of these bees have either only recently been introduced (e.g., [24]), or only recently been discovered as non-native [11]. It is particularly important to understand these impacts as bees continue to be accidentally introduced by humans, and expand their distributions in response to disturbance and climate change. As other authors have noted (e.g., [19]), conducting experiments to demonstrate some of the aforementioned impacts can be challenging, but with multiple studies in disparate locations, we can get a better understanding of the overall context dependence of negative and positive species impacts.

Future research should explore the impacts of bees beyond their roles as pollinators or competitors in ecological communities, for example, as prey in altered trophic webs. A sudden influx of a highly abundant food source, even if it is novel, might have implications for some predators [137]. It may change the population dynamics of insectivorous birds, generalist insect predators, or insects that prey solely on bees, such as beewolves [138]. There may also be interesting impacts of non-native bees on public perception of important ecological issues [139].

As is sometimes the case with introduced species [140], some of the bee species that are considered invasive in their introduced range have become quite rare in their native range, such as Bombus ruderatus [141] and B. subterraneous [142]. The management options for these bees in their introduced range are more complicated because conservation in their native range is also a concern. Indeed, some breeding programs for reintroduction of these Bombus species are being developed in their non-native range in New Zealand [143].

\section{Conclusions}

Invasive non-native bees present a complex topic because their negative impacts may be inextricably tied to the pollination services they provide to humans and the potential positive impacts they have in their role as pollinators. Whether or not they can have a dramatic effect on native communities and ecosystems or whether anthropogenic impacts such as habitat degradation are driving changes in community structure is unknown and probably understudied [85,144]. However, concerns about non-native bees exist, especially when their ranges expand rapidly, and for the majority of introduced bee species little or nothing is known. Thus, their role in novel ecosystems should be addressed, weighing both positive and negative influences they have on native species.

Supplementary Materials: The following are available online at http://www.mdpi.com/2075-4450/7/4/69/s1. Table S1: Selected references of potential negative impacts of Apis or Bombus species; Table S2: Selected references for potential positive impacts of Apis or Bombus species. Figure S1: Frequency histogram of first collection records for introduced bee species. Note that dates of introduction are approximated and for most species have not been carefully studied.

Acknowledgments: I would to acknowledge help from the many researchers who contributed observations or references on non-native bees, including Alfredo Valido, Sam Droege, Amber D. Tripodi, Jonathan B. Koch, Michael Orr, Elias H. Bloom, Jason Gibbs, Russel Barsh, Rufus Isaacs, Evan A. Sugden, Jim Cane, Jack Neff, Heather Moylett, Colin Phifer, Richard Orr, and Don Harvey. Thanks to Joe Keller and Eric Allen for friendly reviews. This work was funded by the Pennsylvania State University and National Science Foundation (grant \#DMS-1313115).

Conflicts of Interest: The author declares no conflict of interest. 


\section{References}

1. Lovett, G.M.; Weiss, M.; Liebhold, A.M.; Holmes, T.P.; Leung, B.; Lambert, K.F.; Orwig, D.A.; Campbell, F.T.; Rosenthal, J.; McCullough, D.G.; et al. Nonnative forest insects and pathogens in the United States: Impacts and policy options. Ecol. Appl. 2016, 26, 1437-1455. [CrossRef] [PubMed]

2. Kovacs, K.F.; Haight, R.G.; McCullough, D.G.; Mercader, R.J.; Siegert, N.W.; Liebhold, A.M. Cost of potential emerald ash borer damage in U.S. communities, 2009-2019. Ecol. Econ. 2010, 69, 569-578. [CrossRef]

3. Gray, M.E.; Sappington, T.W.; Miller, N.J.; Moeser, J.; Bohn, M.O. Adaptation and Invasiveness of Western Corn Rootworm: Intensifying Research on a Worsening Pest. Annu. Rev. Entomol. 2009, 54, 303-321. [CrossRef] [PubMed]

4. Pimentel, D.; Zuniga, R.; Morrison, D. Update on the environmental and economic costs associated with alien-invasive species in the United States. Ecol. Econ. 2005, 52, 273-288. [CrossRef]

5. Morales, C.L.C.; Arbetman, M.M.P.; Cameron, S.A.; Aizen, M.A. Rapid ecological replacement of a native bumble bee by invasive species. Front. Ecol. Environ. 2013, 11, 529-534. [CrossRef]

6. Wenner, A.; Thorp, R.; Barthell, J. Biological control and eradication of feral honey bee colonies on Santa Cruz Island, California: A summary. In Proceedings of the 7th California Islands Symposium Institute Foe Wildlife Studies, Arcata, CA, USA, 5-8 February 2008.

7. Schlaepfer, M.A.; Sax, D.F.; Olden, J.D. The Potential Conservation Value of Non-Native Species. Conserv. Biol. 2011, 25, 428-437. [CrossRef] [PubMed]

8. Montalva, J.; Packer, L. First record of the bee Chilicola (Pseudiscelis) rostrata (Friese, 1906) (Colletidae: Xeromelissinae) in Chile: A recent adventive species to the country? Bol. Biodivers. Chile 2012, 7, 63-65.

9. Snelling, R. Bees of the Hawaiian Islands, exclusive of Hylaeus (Nesoprosopis)(Hymenoptera: Apoidea). J. Kansas Entomol. Soc. 2003, 76, 342-356.

10. Tonietto, R.; Ascher, J.S. Occurrence of the Old World bee species Hylaeus hyalinatus, Anthidium manicatum, A. oblongatum, and Megachile sculpturalis, and the native species Coelioxys banksi, Lasioglossum michiganense, and L. zophops in Illinois (Hymenoptera: Apoidea: Colletidae, Halictidae, Megachilidae). Gt. Lakes Entomol. 2008, 41, 200-203.

11. Sheffield, C.; Dumesh, S.; Cheryomina, M. Hylaeus punctatus (Hymenoptera: Colletidae), a bee species new to Canada, with notes on other non-native species. J. Entomol. Soc. Ont. 2011, 142, 29-43.

12. Donovall, L.R.; vanEngelsdorp, D. A Checklist of the Bees (Hymenoptera: Apoidea) of Pennsylvania. J. Kansas Entomol. Soc. 2010, 83, 7-24. [CrossRef]

13. Magnacca, K.N.; Nagamine, W.T.; Dathe, H.H. Hylaeus strenuus (Hymenoptera: Colletidae), a new alien bee on O'ahu. Eldredge Bish. Museum Occas. Pap. 2009, 109, 23-24.

14. Magnacca, K.; Nagamine, W.; Dathe, H. Hylaeus strenuus (Hymenoptera: Colletidae), a new alien bee on O'ahu. In Records of the Hawaii Biological Survey for 2009-2010; Evenhuis, N., Eldredge, L., Eds.; Bishop Museum: Honolulu, HI, USA, 2011; Volume 109, pp. 23-24.

15. Donovan, B. Occurrence of the Australian bee Hyleoides concinna (Hymenoptera: Colletidae) in New Zealand. N. Z. J. Zool. 1983, 10, 345-347. [CrossRef]

16. Giles, V.; Ascher, J. A survey of the bees of the Black Rock Forest preserve, New York (Hymenoptera: Apoidea). J. Hymenopt. Res. 2006, 15, 208-231.

17. Magnacca, K.; King, C. Assessing the Presence and Distribution of 23 Hawaiian Yellow-Faced Bee Species on Lands Adjacent to Military Installations on O'ahu and Hawai'i Island; Pacific Cooperative Studies Unit, University of Hawaii at Manoa: Honolulu, HI, USA, 2013.

18. Magnacca, K.; Gibbs, J.; Droege, S. Notes on alien and native bees (Hymenoptera: Apoidea) from the Hawaiian Islands. Occas. Pap. 2013, 114, 61-65.

19. Goulson, D. Effects of introduced bees on native ecosystems. Annu. Rev. Ecol. Evol. Syst. 2003, 34, 1-26. [CrossRef]

20. Baumann, J.; Walker, K.; Threlfall, C. African Carder bee, "Afranthidium (Immanthidium) repetitum" (Hymenoptera: Megachilidae): A new exotic species for Victoria. Vic. Nat. 2016, 133, 21-25.

21. Gonzalez, V.H.; Griswold, T.; Ayala, R. Two new species of nocturnal bees of the genus Megalopta (Hymenoptera: Halictidae) with keys to species. Rev. Biol. Trop. 2010, 58, 255-263. [CrossRef] [PubMed] 
22. Rasmussen, C.; Carríon, A.; Castro-Urgal, R. Megachile timberlakei Cockerell (Hymenoptera: Megachilidae): Yet another adventive bee species to the Galápagos Archipelago. Pan-Pacific Entomol. 2012, 88, 98-102. [CrossRef]

23. Eickwort, G. Two European species of Chelostoma established in New York State (Hymenoptera: Megachilidae). Psyche (Stuttg) 1980, 87, 315-324. [CrossRef]

24. Notton, D.G.; Tang, C.Q.; Day, A.R. Viper's Bugloss Mason Bee, Hoplitis (Hoplitis) adunca, new to Britain (Hymenoptera, Megachilidae, Megachilinae, Osmiini). Br. J. Entomol. Nat. Hist. 2016, 29, 134-143.

25. Eickwort, G. Hoplitis anthocopoides, a European mason bee established in New York state (Hymenoptera: Megachilidae). Psyche 1970, 77, 190-201. [CrossRef]

26. Groom, S.; Hayes, S.; Ngo, H.; Stevens, M.; Schwarz, M. Recipe for disruption: Multiple recent arrivals of megachilid bees in Pacific archipelagos. J. Insect Conserv. 2014, 18, 613-622. [CrossRef]

27. Gonzalez, V.; Engel, M.; Lucia, M. Species status and new distribution records for Lithurgus huberi (Hymenoptera, Megachilidae, Lithurginae). J. Hymenopt. 2013, 30, 13. [CrossRef]

28. Silva, D.; Gonzalez, V.; Melo, G.; Lucia, M. Seeking the flowers for the bees: Integrating biotic interactions into niche models to assess the distribution of the exotic bee species Lithurgus huberi in South America. Ecological 2014, 273, 200-209. [CrossRef]

29. Vélez-Espino, L.A.; McLaughlin, R.L.; Jones, M.L.; Pratt, T.C. Demographic analysis of trade-offs with deliberate fragmentation of streams: Control of invasive species versus protection of native species. Biol. Conserv. 2011, 144, 1068-1080. [CrossRef]

30. Timberlake, P.H. The discovery of a fifth species of Megachile on Oahu. Proc. Hawaiian Entomol. Soc. 1921, 4, 551-557.

31. Bohart, G. Introduction of foreign pollinators, prospects and problems. Proc. 1st Int. Symp. Pollinat. 1962, 7, 181-188.

32. Genaro, J. Origins, composition and distribution of the bees of Cuba (Hymenoptera: Apoidea: Anthophila). Insecta Mundi 2008, 52, 1-16.

33. Ruz, L. Bee pollinators introduced to Chile: A review. In Pollinating bees: The Conservation Link Between Agriculture and Nature; Kevan, P., Imperatriz-Fonseca, V., Eds.; Ministry of Environment/Brasilia: Brasília, Brazil, 2002; pp. 155-167.

34. Mangum, W.; Brooks, R. First records of Megachile (Callomegachile) sculpturalis Smith (Hymenoptera: Megachilidae) in the continental United States. J. Kansas Entomol. Soc. 1997, 70, 140-142.

35. Westrich, P.; Knapp, A.; Berney, I. Megachile sculpturalis Smith 1853 (Hymenoptera, Apidae), a new species for the bee fauna of Germany, now north of the Alps. Eucera 2015, 9, 3-10.

36. Castro-Urgal, M.; Herrera, H.; Olesen, J. Invaders of pollination networks in the Galápagos Islands. Proc. R. Soc. B-Biol. Sci. 2013, 280, 20123040.

37. Torchio, P.; Asensio, E. The introduction of the European bee, Osmia cornuta Latr into the US as a potential pollinator of orchard crops, and a comparison of its manageability with Osmia. J. Kansas Entomol. Soc. 1985, $58,42-52$.

38. Stubbs, C.; Drummond, F.; Osgood, E. Osmia ribifloris biedermannii and Megachile rotundata (Hymenoptera: Megachilidae) introduced into the lowbush blueberry agroecosystem in Maine. J. Kansas Entomol. Soc. 1994, 67, 173-185.

39. Groom, S.S.V.C.; Stevens, M.M.I.; Ramage, T.; Schwarz, M.P. Origins and implications of apid bees (Hymentopera: Apidae) in French Polynesia. Entomol. Sci. 2016. [CrossRef]

40. Koetz, A. Ecology, behaviour and control of Apis cerana with a focus on relevance to the Australian incursion. Insects 2013, 4, 558-592. [CrossRef] [PubMed]

41. Mito, T.; Uesugi, T. Invasive alien species in Japan: The status quo and the new regulation for prevention of their adverse effects. Glob. Environ. Res. 2004, 8, 171-191.

42. Mogga, J.; Ruttner, F. Apis florea in Africa: Source of the founder population. Bee World 1988, 69, $100-103$. [CrossRef]

43. El Shafie, H.A.F.; Mogga, J.B.B.; Basedow, T. Studies on the possible competition for pollen between the honey bee, Apis mellifera sudanensis, and the imported dwarf honey bee Apis florea (Hym., Apidae) in North-Khartoum (Sudan). J. Appl. Entomol. 2002, 126, 557-562. [CrossRef]

44. Moritz, R.F.A.; Haddad, N.; Bataieneh, A.; Shalmon, B.; Hefetz, A. Invasion of the dwarf honeybee Apis florea into the near East. Biol. Invasions 2010, 12, 1093-1099. [CrossRef] 
45. Haddad, N.; Fuchs, S.; Hepburn, H.R.; Radloff, S.E. Apis florea in Jordan: Source of the founder population. Apidologie 2009, 40, 508-512. [CrossRef]

46. Goulson, D.; Williams, P. Bombus hypnorum (L.)(Hymenoptera: Apidae), a new British bumblebee? Br. J. Entomol. Nat. Hist. 2001, 14, 129-131.

47. Betts, C. Is Bombus hypnorum (Hymenoptera: Apidae) becoming the dominant early-season bumblebee? A back-garden study in east. Br. J. Entomol. Nat. Hist. 2015, 28, 185-191.

48. Ratti, C.; Colla, S. Discussion of the presence of an eastern bumble bee species (Bombus impatiens Cresson) in western Canada. Pan-Pac. Entomol. 2010, 86, 29-31. [CrossRef]

49. Montalva, J.; Dudley, L.; Arroyo, M. Geographic distribution and associated flora of native and introduced bumble bees (Bombus spp.) in Chile. J. Apic. Res. 2011, 50, 11-21. [CrossRef]

50. Torretta, J.; Medan, D.; Abrahamovich, A. First record of the invasive bumblebee Bombus terrestris (L.)(Hymenoptera, Apidae) in Argentina. Trans. Am. Entomol. Soc. 2006, 132, 285-289.

51. Acosta, A.; Giannini, T.; Imperatriz-Fonseca, V. Worldwide alien invasion: A methodological approach to forecast the potential spread of a highly invasive pollinator. PLoS ONE 2016, 11, e0148295. [CrossRef] [PubMed]

52. Groom, S.; Tuiwawa, M.; Stevens, M. Recent introduction of an allodapine bee into Fiji: A new model system for understanding biological invasions by pollinators. Insect Sci. 2015, 22, 532-540. [CrossRef] [PubMed]

53. Shenoy, M.; Borges, R. A novel mutualism between an ant-plant and its resident pollinator. Naturwissenschaften 2008, 95, 61-65. [CrossRef] [PubMed]

54. Silva, C.; Stevens, M.; Schwarz, M. Casteless sociality in an allodapine bee and evolutionary losses of social hierarchies. Insectes Soc. 2016, 63, 67-78. [CrossRef]

55. Fuller, S.; Schwarz, M.; Tierney, S. Phylogenetics of the allodapine bee genus Braunsapis: Historical biogeography and long-range dispersal over water. J. Biogeogr. 2005, 32, 2135-2144. [CrossRef]

56. Downing, J.; Liu, H. Friend or foe? Impacts of the introduced tropical oil bee Centris nitida on a threatened and specialized native mutualism in Southern Florida. Biol. Invasions 2012, 14, 2175-2185. [CrossRef]

57. Daly, H. Biological studies on Ceratina dallatorreana, an alien bee in California which reproduces by parthenogenesis (Hymenoptera: Apoidea). Ann. Entomol. Soc. Am. 1966, 59, 1138-1154. [CrossRef]

58. Skov, C.; Wiley, J. Establishment of the neotropical orchid bee Euglossa viridissima (Hymenoptera: Apidae) in Florida. Fla. Entomol. 2005, 88, 225-227. [CrossRef]

59. López-Uribe, M.; Cane, J. Crop domestication facilitated rapid geographical expansion of a specialist pollinator, the squash bee Peponapis pruinosa. Proc. R. Soc. B Biol. Sci. 2016, 283, 1-9. [CrossRef] [PubMed]

60. Dahlberg, L.; Hauser, M.; Yanega, D. Japanese carpenter bee, Xylocopa appendiculata Smith 1852 (Hymenoptera: Apidae) potentially established in Santa Clara County, first record for North America. Pan-Pac. Entomol. 2013, 89, 226-229. [CrossRef]

61. Montalva, J.; Allendes, J.; Lucia, M. The large carpenter bee Xylocopa augusti (Hymenoptera: Apidae): New record for Chile. J. Melittol. 2013, 12, 1-6. [CrossRef]

62. Barrows, E. Robbing of exotic plants by introduced carpenter and honey bees in Hawaii, with comparative notes. Biotropica 1980, 12, 23-29. [CrossRef]

63. Okabe, K.; Masuya, H.; Kawazoe, K.; Makino, S. Invasion pathway and potential risks of a bamboo-nesting carpenter bee, Xylocopa tranquebarorum (Hymenoptera: Apidae), and its micro-associated mite introduced into Japan. Appl. Entomol. Zool. 2010, 45, 329-337. [CrossRef]

64. Groom, S.; Ngo, H.; Rehan, S.; Skelton, P. Multiple recent introductions of apid bees into Pacific archipelagos signify potentially large consequences for both agriculture and indigenous ecosystems. Biol. Invasions 2014, 16, 2293-2302. [CrossRef]

65. Dickersin, K. Publication bias: Recognizing the problem, understanding its origins and scope, and preventing harm. In Publication bias in meta-analysis: Prevention, Assessment and Adjustments; Rothstein, H.R., Sutton, A.J., Borenstein, M., Eds.; John Wiley \& Sons: San Francisco, CA, USA, 2005; pp. 11-32.

66. Paini, D. Impact of the introduced honey bee (Apis mellifera)(Hymenoptera: Apidae) on native bees: A review. Austral Ecol. 2004, 29, 399-407. [CrossRef]

67. Dafni, A.; Kevan, P.; Gross, C.; Goka, K. Bombus terrestris, pollinator, invasive and pest: An assessment of problems associated with its widespread introductions for commercial purposes. Appl. Entomol. Zool. 2010, 45, 101-113. [CrossRef] 
68. Valido, A.; Rodríguez-Rodríguez, M. Impacto de la introducción de la abeja doméstica (Apis mellifera, Apidae) en el Parque Nacional del Teide (Tenerife, Islas Canarias). Ecosistemas 2014, 23, 58-66. [CrossRef]

69. Abrahamovich, A.; Telleria, M.; Díaz, N. Bombus species and their associated flora in Argentina. Bee World 2001, 82, 76-87. [CrossRef]

70. Moritz, R.; Härtel, S.; Neumann, P. Global invasions of the western honeybee (Apis mellifera) and the consequences for biodiversity. Ecoscience 2005, 12, 289-301. [CrossRef]

71. Rust, R.; Cambon, G.; Grossa, J. Nesting biology and foraging ecology of the wood-boring bee Lithurgus chrysurus (Hymenoptera: Megachilidae). J. Kansas 2004, 77, 269-279. [CrossRef]

72. Rozen, J.; Wyman, E. Early nesting biology of the wood-nesting adventive bee, Lithurgus chrysurus Fonscolombe (Apoidea: Megachilidae: Lithurginae). Am. Museum Novit. 2014, 3804, 1-12. [CrossRef]

73. Gibbs, J.; Sheffield, C. Rapid range expansion of the Wool-Carder Bee, Anthidium manicatum (Linnaeus)(Hymenoptera: Megachilidae), in north america. J. Kansas Entomol. Soc. 2009, 82, 21-29. [CrossRef]

74. Bosch, J. Parasitism in wild and managed populations of the almond pollinator Osmia cornuta Latr.(Hymenoptera: Megachilidae). J. Apic. Res. 1992, 31, 77-82. [CrossRef]

75. McKinney, M.; Park, Y. Distribution of Chaetodactylus krombeini (Acari: Chaetodactylidae) within Osmia cornifrons (Hymenoptera: Megachilidae) nests: Implications for population. Exp. Appl. Acarol. 2013, 60, 153-161. [CrossRef] [PubMed]

76. Magnacca, K.N. Conservation status of the endemic bees of Hawai'i, Hylaeus (Nesoprosopis) (Hymenoptera: Colletidae). Pac. Sci. 2007, 61, 173-190. [CrossRef]

77. MacIvor, J.S.; Cabral, J.M.; Packer, L. Pollen specialization by solitary bees in an urban landscape. Urban Ecosyst. 2014, 17, 139-147. [CrossRef]

78. Soper, J.; Beggs, J. Assessing the impact of an introduced bee, Anthidium manicatum, on pollinator communities in New Zealand. N. Z. J. Bot. 2013, 51, 213-228. [CrossRef]

79. Barthell, J.; Frankie, G. Invader effects in a community of cavity nesting megachilid bees (Hymenoptera: Megachilidae). Environ. Entomol. 1998, 27, 240-247. [CrossRef]

80. Frankie, G.; Thorp, R. Monitoring solitary bees in modified wildland habitats: Implications for bee ecology and conservation. Environ. Entomol. 1998, 27, 1137-1148. [CrossRef]

81. Mciver, J.; Thorp, R.; Erickson, K. Pollinators of the invasive plant, yellow starthistle (Centaurea solstitialis), in north-eastern Oregon, USA. Weed Biol. Manag. 2009, 9, 137-145. [CrossRef]

82. Alvarez, L.; Lucia, M.; Aquino, D. Nesting biology and associated insect enemies of the exotic leaf cutter bee Megachile (Eutricharaea) concinna (Hymenoptera: Megachilidae) in Argentina. J. Apic. Res. 2016, 54, 305-313. [CrossRef]

83. Donovan, B. Interactions between native and introduced bees in New Zealand. N. Z. J. Ecol. 1980, 3, $104-116$.

84. Woodward, D. Monitoring for impact of the introduced leafcutting bee, Megachile rotundata (F.)(Hymenoptera: Megachilidae), near release sites in South Australia. Aust. J. Entomol. 1996, 35, 187-191. [CrossRef]

85. Howlett, B.; Donovan, B. A review of New Zealand's deliberately introduced bee fauna: current status and potential impacts. N. Z. Entomol. 2010, 33, 92-101. [CrossRef]

86. Hedtke, S.; Blitzer, E.; Montgomery, G.; Danforth, B. Introduction of non-native pollinators can lead to trans-continental movement of bee-associated fungi. PLoS ONE 2015, 10, e0130560. [CrossRef] [PubMed]

87. Laport, R.; Minckley, R. Occupation of active Xylocopa virginica nests by the recently invasive Megachile sculpturalis in upstate New York. J. Kansas Entomol. Soc. 2012, 85, 384-386. [CrossRef]

88. Parys, K.; Tripodi, A.; Sampson, B. The Giant Resin Bee, Megachile sculpturalis Smith: New Distributional Records for the Mid-and Gulf-south USA. Biodivers. Data J. 2015, 3, e6733. [CrossRef] [PubMed]

89. Mangum, W.; Sumner, S. A survey of the North American range of Megachile (Callomegachile) sculpturalis, an adventive species in North America. J. Kansas Entomol. Soc. 2003, 76, 658-662.

90. Quaranta, M.; Sommaruga, A.; Balzarini, P. A new species for the bee fauna of Italy: Megachile sculpturalis continues its colonization of Europe. Bull. Insectol. 2014, 67, 287-293.

91. Hodge, S.; Prasad, A. Factors influencing the foraging activity of the allodapine bee Braunsapis puangensis on creeping daisy (Sphagneticola trilobata) in Fiji. J. Hymenopt. Res. 2013, 35, 56-69. [CrossRef]

92. Liu, H.; Pemberton, R. Pollination of an invasive orchid, Cyrtopodium polyphyllum (Orchidaceae), by an invasive oil-collecting bee, Centris nitida, in southern Florida. Botany 2010, 88, 290-295. [CrossRef]

93. Pemberton, R.; Liu, H. Potential of invasive and native solitary specialist bee pollinators to help restore the rare cowhorn orchid (Cyrtopodium punctatum) in Florida. Biol. Conserv. 2008, 141, 1758-1764. [CrossRef] 
94. Liu, H.; Pemberton, R. Solitary invasive orchid bee outperforms co-occurring native bees to promote fruit set of an invasive Solanum. Oecologia 2009, 159, 515-525. [CrossRef] [PubMed]

95. Howarth, F. Impacts of alien land arthropods and mollusks on native plants and animals in Hawaii; University of Hawai'i Press: Honolulu, HI, USA, 1985.

96. Kawazoe, K.; Okabe, K.; Kawakita, A. An alien Sennertia mite (Acari: Chaetodactylidae) associated with an introduced Oriental bamboo-nesting large carpenter bee (Hymenoptera: Apidae: Xylocopa). Entomol. Sci. 2010, 13, 303-310. [CrossRef]

97. Goka, K.; Okabe, K.; Takano, A. Recent cases of invasive alien mites and ticks in Japan: Why is a regulatory framework needed? Exp. Appl. Acarol. 2013, 59, 245-261. [CrossRef] [PubMed]

98. Kremen, C.; Williams, N.M.; Aizen, M.A.; Gemmill-Herren, B.; LeBuhn, G.; Minckley, R.; Packer, L.; Potts, S.G.; Roulston, T.; Steffan-Dewenter, I.; et al. Pollination and other ecosystem services produced by mobile organisms: A conceptual framework for the effects of land-use change. Ecol. Lett. 2007, 10, 299-314. [CrossRef] [PubMed]

99. Winfree, R.; Williams, N.M.; Dushoff, J.; Kremen, C. Native bees provide insurance against ongoing honey bee losses. Ecol. Lett. 2007, 10, 1105-1113. [CrossRef] [PubMed]

100. Carvalheiro, L.G.; Veldtman, R.; Shenkute, A.G.; Tesfay, G.B.; Pirk, C.W.W.; Donaldson, J.S.; Nicolson, S.W. Natural and within-farmland biodiversity enhances crop productivity. Ecol. Lett. 2011, 14, 251-259. [CrossRef] [PubMed]

101. Garibaldi, L.A.; Steffan-Dewenter, I.; Winfree, R.; Aizen, M.A.; Bommarco, R.; Cunningham, S.A.; Kremen, C.; Carvalheiro, L.G.; Harder, L.D.; Afik, O.; et al. Wild pollinators enhance fruit set of crops regardless of honey bee abundance. Science 2013, 339, 1608-1611. [CrossRef] [PubMed]

102. Greenleaf, S.S.; Kremen, C. Wild bees enhance honey bees' pollination of hybrid sunflower. Proc. Natl. Acad. Sci. USA 2006, 103, 13890-13895. [CrossRef] [PubMed]

103. Losey, J.E.; Vaughan, M. The Economic Value of Ecological Services Provided by Insects. Bioscience 2006, 56, 311. [CrossRef]

104. Felicioli, A.; Bedini, G.; Soci, M.; Pinzauti, M. Detection of lead in the environment by using the pedotrophic cell of Osmia cornuta (Hymenoptera, Megachilidae). Ann. Della Fac. 2006, 59, 263-273.

105. O’Brien, M.; Swanson, D.; Monsma, J. Anthidium oblongatum (Apoidea: Megachilidae) confirmed as a Michigan resident, with notes on other Michigan Anthidium species. Gt. Lakes Entomol. 2012, 45, 102-105.

106. Sanguinetti, A.; Singer, R. Invasive bees promote high reproductive success in Andean orchids. Biol. Conserv. 2014, 175, 10-20. [CrossRef]

107. Packer, L.; Zayed, A.; Grixti, J.; Ruz, L. Conservation genetics of potentially endangered mutualisms: Reduced levels of genetic variation in specialist versus generalist bees. Conserv. Biol. 2005, 19, 195-202. [CrossRef]

108. Adamson, N.; Fell, R.; Mullins, D.; Kennedy, L. An Assessment of non-Apis Bees as fruit and Vegetable Crop Pollinators; Virginia Polytechnic Institute and State University: Blacksburg, VA, USA, 2011.

109. Cane, J. Ground-nesting bees: The neglected pollinator resource for agriculture. Acta Hortic. 1997, 437, 309-324. [CrossRef]

110. Cane, J. A native ground-nesting bee (Nomia melanderi) sustainably managed to pollinate alfalfa across an intensively agricultural landscape. Apidologie 2008, 39, 315-323. [CrossRef]

111. Payne, A.; Schildroth, D.; Starks, P. Nest site selection in the European wool-carder bee, Anthidium manicatum, with methods for an emerging model species. Apidologie 2011, 42, 181-191. [CrossRef]

112. Praz, C.; Müller, A.; Dorn, S. Specialized bees fail to develop on non-host pollen: Do plants chemically protect their pollen. Ecology 2008, 89, 795-804. [CrossRef] [PubMed]

113. Parker, F.; Torchio, P.; Nye, W. Utilization of additional species and populations of leafcutter bees for alfalfa pollination. J. Apic. Res. 1976, 15, 89-92. [CrossRef]

114. Kearns, C.A.; Inouye, D.W.; Waser, N.M. Endangered Mutualisms: The Conservation of Plant-Pollinator Interactions. Annu. Rev. Ecol. Syst. 1998, 29, 83-112. [CrossRef]

115. Brading, P.; El-Gabbas, A.; Zalat, S.; Gilbert, F. Biodiversity economics: the value of pollination services to Egypt. Egypt. J. Biol. 2009, 11, 46-51.

116. Pitts-Singer, T.; Cane, J. The Alfalfa leafcutting bee, Megachile rotundata: The World's most intensively managed solitary bee. Annu. Rev. Entomol. 2011, 56, 221-237. [CrossRef] [PubMed] 
117. Stephen, W.; Osgood, C. The induction of emergence in the leaf-cutter bee Megachile rotundata, an important pollinator of alfalfa. J. Econ. Entomol. 1965, 58, 284-286. [CrossRef]

118. Cane, J.; Neff, J. Predicted fates of ground-nesting bees in soil heated by wildfire: Thermal tolerances of life stages and a survey of nesting depths. Biol. Conserv. 2011, 144, 2631-2636. [CrossRef]

119. Pitts-Singer, T.; Buckner, J. Structural Examination of the Dufour's Gland of the Solitary Bees Osmia lignaria and Megachile rotundata (Hymenoptera: Megachilidae). Ann. Entomol. Soc. Am. 2012, 105, 103-110. [CrossRef]

120. Cane, J.; Tepedino, V. Gauging the effect of honey bee pollen collection on native bee communities. Conserv. Lett. 2016. [CrossRef]

121. Abel, C.; Wilson, R. The use of diverse plant species for increasing Osmia cornifrons (Hymenoptera: Megachilidae) in field cages. J. Kansas Entomol. Soc. 1998, 71, 23-28.

122. West, T.; McCutcheon, T. Evaluating Osmia cornifrons as pollinators of highbush blueberry. Int. J. Fruit Sci. 2009, 9, 115-125. [CrossRef]

123. Matsumoto, S.; Maejima, T. Several new aspects of the foraging behavior of Osmia cornifrons in an apple orchard. Psyche A J. Entomol. 2010, 53, 4633-4641.

124. Biddinger, D.; Joshi, N.; Rajotte, E.; Halbrendt, N. An immunomarking method to determine the foraging patterns of Osmia cornifrons and resulting fruit set in a cherry orchard. Apidologie 2013, 44, 738-749. [CrossRef]

125. Wilson, R.; Abel, C. Storage conditions for maintaining Osmia cornifrons (Hymenoptera: Megachilidae) for use in germplasm pollination. J. Kansas Entomol. Soc. 1996, 69, 270-272.

126. Biddinger, D.; Robertson, J.; Mullin, C.; Frazier, J. Comparative toxicities and synergism of apple orchard pesticides to Apis mellifera (L.) and Osmia cornifrons (Radoszkowski). PLoS ONE 2013, 8, e72587. [CrossRef] [PubMed]

127. Lee, K.; Yoon, H.; Jin, B. Osmia cornifrons vitellogenin: cDNA cloning, structural analysis and developmental expression. Entomol. Res. 2015, 45, 94-101. [CrossRef]

128. Vicens, N.; Bosch, J. Pollinating efficacy of Osmia cornuta and Apis mellifera (Hymenoptera: Megachilidae, Apidae) on "red Delicious" apple. Environ. Entomol. 2000, 29, 235-240. [CrossRef]

129. Nogué, S.; Long, P.; Eycott, A.; Nascimento, L. de Pollination service delivery for European crops: Challenges and opportunities. Ecol. Econ. 2016, 128, 1-7. [CrossRef]

130. Maccagnani, B.; Giacomello, F.; Fanti, M.; Gobbin, D. Apis mellifera and Osmia cornuta as carriers for the secondary spread of Bacillus subtilis on apple flowers. BioControl 2009, 54, 123. [CrossRef]

131. Lozo, J.; Berić, T.; Terzić-Vidojević, A. Microbiota associated with pollen, bee bread, larvae and adults of solitary bee Osmia cornuta (Hymenoptera: Megachilidae). Bull. Entomol. Res. 2015, 105, 470-476. [CrossRef] [PubMed]

132. Bond, D.; Kirby, E. Anthophora plumipes (Hymenoptera: Anthophoridae) as a pollinator of broad bean (Vicia faba major). J. Apic. Res. 1999, 38, 199-203. [CrossRef]

133. Silva, D.; Groom, S.; Silva, C. Potential pollination maintenance by an exotic allodapine bee under climate change scenarios in the Indo-Pacific region. J. Appl. Entomol. 2016. [CrossRef]

134. Ali, H.; Alqarni, A.; Shebl, M.; Engel, M. Notes on the nesting biology of the small carpenter bee Ceratina smaragdula (Hymenoptera: Apidae) in northwestern Pakistan. Florida Entomol. 2016, 99, 89-93. [CrossRef]

135. Pemberton, R.; Wheeler, G. Orchid bees don't need orchids: Evidence from the naturalization of an orchid bee in Florida. Ecology 2006, 87, 1995-2001. [CrossRef]

136. Minter, L.M.; Bessin, R.T. Evaluation of Native Bees as Pollinators of Cucurbit Crops under Floating Row Covers. Environ. Entomol. 2014, 43, 1354-1363. [CrossRef] [PubMed]

137. Pintor, L.M.; Byers, J.E. Do native predators benefit from non-native prey? Ecol. Lett. 2015, 18, 1174-1180. [CrossRef] [PubMed]

138. Stubblefield, J.W.; Seger, J.; Wenzel, J.W.; Heisler, M.M. Temporal, Spatial, Sex-Ratio and Body-Size Heterogeneity of Prey Species Taken by the Beewolf Philanthus sanbornii (Hymenoptera: Sphecidae). Philos. Trans. R. Soc. Lond. B Biol. Sci. 1993, 339, 397-423. [CrossRef] [PubMed]

139. Smith, T.; Saunders, M. Honey bees: The queens of mass media, despite minority rule among insect pollinators. Insect Conserv. Divers. 2016, 9, 384-390. [CrossRef]

140. Marchetti, M.P.; Engstrom, T. The conservation paradox of endangered and invasive species. Conserv. Biol. 2016, 30, 434-437. [CrossRef] [PubMed]

141. Bartlett, M.; Hale, R.; Hale, M. Habitat quality limits gene flow between populations of Bombus ruderatus in the South Island, New Zealand. Conserv. Genet. 2016, 17, 703-713. [CrossRef] 
142. Howlett, B.; Donovan, B.; Read, R.; Hale, R. Rearing Bombus subterraneus for re-introduction into Great Britain. Weta 2009, 37, 10-12.

143. Lye, G.; Kaden, J.; Park, K.; Goulson, D. Forage use and niche partitioning by non-native bumblebees in New Zealand: Implications for the conservation of their populations of origin. J. Insect Conserv. 2010, 14, 607-615. [CrossRef]

144. Wehling, W.; Flanders, R. The Risks of International Trade in Bees: Laws and Regulations on the Import, Movement and Release of Bees in the United States. Bee Res. Virus Eur. 2005, 6, 301-309.

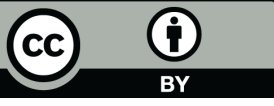

(C) 2016 by the author; licensee MDPI, Basel, Switzerland. This article is an open access article distributed under the terms and conditions of the Creative Commons Attribution (CC-BY) license (http://creativecommons.org/licenses/by/4.0/). 